ROCZNIKI PEDAGOGICZNE

Tom 11(47), numer 4 - 2019

DOI: http://dx.doi.org/10.18290/rped.2019.11.4-6

EWA ROJEWSKA

\title{
TERAPIA SYSTEMOWA JAKO FORMA POMOCY RODZINIE
}

„Mówiąc krótko, nasz świat, świat płynnej nowoczesności, nieustannie nas zaskakuje: to, co dziś wydaje się pewne i na właściwym miejscu, już jutro może okazać się żałosną pomyłką, czymś płonnym i niedorzecznym. Podejrzewamy, że może tak się stać, dlatego czujemy, że podobnie jak świat, który jest naszym domem, także my, jego mieszkańcy, od czasu do czasu jego projektanci, aktorzy, użytkownicy i ofiary, musimy być stale przygotowani na zmiany, musimy być, zgodnie z modnym ostatnio określeniem, 'elastyczni”' (Bauman, 2011, s. 6).

Rzeczywistość zachodniego świata XXI wieku niesie dla rodziny wiele wyzwań. Nie wchodząc $w$ naukowe spory dotyczące tego, czy współczesna rodzina znajduje się w kryzysie, czy też może w naturalny sposób przechodzi transformację (Kwak, 2005), można stwierdzić, że oprócz szans rozwojowych, ponowoczesność będąca kontekstem życia współczesnych rodzin, niesie z sobą wiele wyzwań, a niekiedy i zagrożeń. Do szczególnie jaskrawo zaznaczających się zmian i zjawisk dotyczących rodziny zaliczyć można zmianę modelu funkcjonowania rodzin, upowszechnienie modelu małżeństwa dwu-karier, emigrację zarobkową, znaczną ilość rozwodów, zmianę modelu zachowań seksualnych i prokreacyjnych, zmiany w realizacji funkcji wychowawczej rodziny czy też upowszechnienie się alternatywnych form życia rodzinnego. Rodziny funkcjonują w określonym kontekście kulturowym, w tym obszarze również obserwuje się wiele zjawisk istotnych z familiologicznego punktu widzenia. Wymienić tu można choćby popkulturę, feminizm, globalizację czy też konsumpcjonizm.

Zasygnalizowane zmiany (jest ich znacznie więcej niż wymienione powyżej) dokonują się $\mathrm{z}$ niespotykaną $\mathrm{w}$ historii dotąd prędkością. W systemie jednej

Dr EwA RoJEWSKA - doktor nauk społecznych w zakresie pedagogiki; Instytut Pedagogiki Uniwersytetu Szczecińskiego; adres do korespondencji - e-mail: ewa.rojewska@usz.edu.pl; ORCID: https://orcid.org/0000-0003-3988-810X. 
rodziny mogą żyć z sobą osoby (pokolenia) z diametralnie różnymi doświadczeniami współczesności. Wszystkie te okoliczności sprawiają, że rodzina może doświadczać wielu sytuacji wymagających wsparcia jej z zewnątrz. Należy przy tym dodać, że oprócz zasygnalizowanych zewnętrznych czynników, które potencjalnie mogą przyczyniać się do powstawania trudności w życiu rodzinnym, istnieje wiele niezależnych od nich powodów predysponujących rodzinę do udzielenia jej pomocy - np. choroby członków rodziny czy inne normatywne kryzysy w życiu rodzinnym, jak na przykład urodzenie się dziecka.

O potrzebie i możliwościach pomocy rodzinie mówi się współcześnie coraz więcej. Opracowywane są rządowe programy wspierania rodziny, rozwija się i umacnia również rynek usług psychoterapeutycznych. Zwiększa się świadomość społeczna dotycząca form wsparcia psychologicznego oraz powoli zmniejsza się tabu dotyczące leczenia psychiatrycznego i psychoterapeutycznego. Istnieje wiele szkół psychoterapeutycznych oferujących pomoc klientom doświadczającym rozmaitych problemów. W ostatnich latach w Polsce coraz bardziej popularna i dostępna staje się terapia systemowa. Choć z jej możliwości pomocy mogą korzystać osoby indywidualne, to w sposób szczególny wydaje się ona użyteczna w przypadku rodzin. W znacznie większym stopniu zwraca ona uwagę na problemy całej rodziny niż inne podejścia terapeutyczne.

Celem niniejszego artykułu jest przedstawienie terapii systemowej jako możliwej i skutecznej formy pomocy rodzinie. Tekst zawiera treści związane z systemowym rozumieniem rodziny oraz znaczeniem systemu rodzinnego dla jakości życia jego członków. Po tym koniecznym wprowadzeniu, druga część artykułu poświęcona jest istocie i użyteczności systemowej terapii rodzin w perspektywie możliwości wykorzystania jej w procesach pomocy rodzinom. Artykuł nie rości sobie praw do wyczerpującego przedstawienia wszystkich treści związanych z systemową terapią rodzin i systemowym rozumieniem rodziny, ale zawiera te, które są konieczne dla ukazania terapii systemowej jako wartej uwagi formy pomocy rodzinom.

\section{SYSTEMOWE ROZUMIENIE RODZINY}

Pojęcie „rodzina” może być definiowane na wiele różnych sposobów. W jej opisie można przyjąć perspektywę pedagogiczną, psychologiczną, historyczną, prawną, socjologiczną czy wreszcie indywidualną - uwzględniającą osobiste doświadczenia i przekonania poszczególnych osób. Wielość tych perspektyw, 
wielowymiarowość życia rodzinnego, jak również fakt dokonujących się intensywnych i znaczących jego przemian oraz pojawianie nowych, nieobecnych dotąd lub obecnych marginalnie jego form, sprawia, że ułożenie jednej, pełnej definicji rodziny jest zadaniem niezmiernie trudnym. Na gruncie systemowej terapii rodzin nie jest to zresztą zadaniem koniecznym. Wystarczające jest wewnętrzne i uświadomione przekonanie klientów dotyczące definicji i granic jego rodziny, a zatem istotna jest tu perspektywa indywidualna.

Podejście systemowe w teorii i terapii rodzin ma swoje źródło w ogólnej teorii systemów. Za datę jej powstania przyjmuje się 1954 r. i wiąże z osobą wiedeńskiego biologa, L. von Bertalanffyego (Drożdżewicz, 1999). Na gruncie problematyki rodzinnej podejście systemowe zostało rozwinięte przez S. Minuchina, twórcę strukturalnej teorii rodzin oraz M. Bowena, twórcę teorii systemów rodzinnych (Bajkowski, 2018). W poniższym fragmencie artykułu zostaną przedstawione właściwości rodziny postrzeganej w optyce systemowej.

Grecki termin systema oznacza złożoną rzecz. Korzystając z arystotelesowskiej definicji, przyjmuje się, że system jest uporządkowaną kompozycją elementów tworzących spójną całość, przy czym ta całość nie jest zwykłą sumą jej części. Zatem rodzina jako system stanowi nową, niepowtarzalną jakość (Drożdżewicz, 1999). Nie można powiedzieć, że jest jedynie zbiorem tworzących ją osób, ale w wyniku łączących te osoby relacji, staje się unikalnym bytem o niepowtarzalnych w żadnym innym systemie rodzinnym cechach.

Rodzina jako system posiada określoną strukturę. Rozumie się ją szeroko „jako zespół funkcjonalnych wymagań, wypełnianych przez określoną osobę (osoby) i oczekiwań, jakie wobec tej osoby (osób) są kierowane" (Świętochowski, 2017, s. 27). Strukturę rodziny tworzą przede wszystkim jej członkowie wraz z całym bogactwem swoich indywidualności. Elementami struktury rodziny są także podsystemy, granice oraz role i pozycje rodzinne.

System rodzinny posiada zewnętrzne i wewnętrzne granice. Granice zewnętrze oddzielają system rodziny od innych systemów (np. szkolnego, koleżeńskiego, społecznego), granice wewnętrzne zaś istnieją pomiędzy poszczególnymi członkami rodziny lub pomiędzy podsystemami w ramach jednej rodziny. Główną funkcją granic jest ochrona systemu przed utratą tożsamości. Aby jednak granice mogły spełniać swój cel, powinny charakteryzować się elastycznością i przepuszczalnością. Jeśli granice systemu są zbyt sztywne lub też rozmyte, system traci swoją zdolność utrzymania homeostazy i albo kostnieje niezdolny do dostosowania się do pojawiających się zmian związanych z cyklem życia rodzinnego (lub 
też innych, nieprzewidzianych zmian), albo traci swoją unikatową tożsamość i grozi mu rozpad (Świętochowski, 2017; Bajkowski, 2018).

W systemie rodzinnym wyróżnić można podsystemy. Różnorodne mogą być kryteria podziału - np. wiek, płeć czy pełnione role. Może istnieć tak wiele podsystemów, jak wiele może być kryteriów ich podziału. Najjaskrawiej zaznacza się podsystem rodzicielski jako ten, który determinuje funkcjonowanie całego systemu rodzinnego i poszczególnych jego podsystemów. Podsystem może składać się z jednej, dwóch lub kilku osób. Osoba może przynależeć w tym samym czasie do kilku różnych podsystemów. Te zaś mogą ulegać modyfikacji, rozpadać się lub powstawać na nowo. Podział na podsystemy jest zależny od fazy życia rodzinnego, aktualnych potrzeb, zasobów i ograniczeń rodziny. Ma on charakter dynamiczny (Świętochowski, 2017).

W szerokim spectrum struktury rodziny mieszczą się również specyficzne elementy danego systemu rodzinnego, które w innej rodzinie mogą być nieobecne lub nie mieć specjalnego znaczenia. Chodzi tu o wszystkie elementy życia rodzinnego, które wpływają istotnie na uczucia, postawy, relacje, zachowania członków rodziny, które w jakiś sposób regulują życie rodzinne. Mogą więc to być na przykład zobowiązania, tradycje, oczekiwania, choroby, tragiczne wydarzenia rodzinne, rytuały czy jakiekolwiek inne elementy istotne z perspektywy funkcjonowania danej rodziny (de Barbaro, 1997; Świętochowski, 2017).

Kolejną ważną cechą systemu rodzinnego jest ta, że zmiana w jednej części systemu rodzinnego zawsze, nieuchronnie, powoduje zmiany w całym systemie, a więc odnosi się do wszystkich tworzących go osób (Drożdżewicz, 1999). Ta cecha uwypukla, jak istotne znaczenie ma każdy członek rodziny dla systemu rodzinnego, który współtworzy oraz jak istotne dla jego funkcjonowania są łączące członków rodziny więzy. Jednocześnie zmiany dotyczące całego systemu, nieuchronnie pociągają za sobą reakcję, a więc zmianę każdego członka systemu. Nie ma możliwości abstrahowania od zmian dotykających system jako całość albo któregokolwiek z jego członków. Można przyrównać to do pierwszego aksjomatu komunikacji P. Walzlawika, który mówi o tym, że osoba nie może nie komunikować. Nawet gdy nie chcemy komunikować, stanowi to komunikat. Analogicznie, nawet gdy jeden z członków systemu rodzinnego nie chce dopuścić do świadomości określonej zmiany $\mathrm{w}$ rodzinie, to jest to jednak pewna reakcja, która rzutuje na sieć relacji wewnątrzrodzinnych.

Z powyżej wskazaną cechą łączą się dwie zasady funkcjonowania systemu rodzinnego, to jest ekwipotencjalność i ekwifinalność. Ekwipotencjalność oznacza, że przyczyny mające to samo źródło mogą powodować różne konsekwencje. 
W myśl ekwifinalności, wychodząc z różnych źródeł, można osiągnąć te same rezultaty (Drożdżewicz, 1999). Zasady te uwidaczniają, jakim bogactwem różnorodności zachowań i reakcji cechować się może każda rodzina. Ich analiza prowadzi również do konstatacji, że w systemie rodzinnym nie istnieje prosta przyczynowość linearna.

W systemowym rozumieniu rodziny miejsce przyczynowości linearnej zajmuje przyczynowość kolista. Poszczególne elementy systemu rodzinnego wzajemnie na siebie oddziałują w sposób cyrkularny na zasadzie sprzężenia zwrotnego (Józefik, 2003). Każda zmiana w jednym elemencie systemu lub w jednym z podsystemów wywołuje zmiany we wszystkich innych elementach systemu i wszystkich innych podsystemach. Przyjęcie modelu sprzężenia zwrotnego w komunikacji i relacjach rodzinnych ma przełożenie na model diagnostyczny w terapii rodzin. Liniowy model diagnostyczny (gdzie określona przyczyna wywołuje określony skutek) zastępuje się modelem wieloczynnikowym (gdzie wiele przyczyn może mieć wiele skutków) (Bajkowski, 2018).

$\mathrm{W}$ analizie funkcjonowania systemu rodzinnego ważne jest również dostrzeżenie dwóch zachodzących w nich procesów - morfostatycznego i morfogenetycznego. Proces morfostatyczny zmierza do zachowania stałości w systemie, morfogentyczny - do rozwoju i zmiany. Te dwie przeciwstawne siły powinny pozostawać $\mathrm{w}$ równowadze. Jeśli w systemie rodzinnym przeważają dążenia morfostatyczne, pozostanie on skostniały i niezdolny do efektywnego dostosowania się do nieuchronnych zmian (przykładem może być niezwiększanie zakresu wolności dzieciom wraz $\mathrm{z}$ ich dojrzewaniem). Jeśli natomiast $\mathrm{w}$ systemie rodzinnym przeważają dążenia morfogenetyczne, system rodzinny może utracić swoją tożsamość, a nawet w obliczu radykalnych zmian ulec rozpadowi (przykładem może być otwarcie granic wolności dorastającego dziecka do tego stopnia, że nie uznaje się wartości rodziny za istotne w wolnych wyborach nastolatka). Procesy morfogenetyczny i morfostatyczny są w systemach rodzinnych regulowane przez dwa procesy: mechanizm sprzężenia zwrotnego ujemnego i dodatniego. Ten pierwszy polega na tym, że zmniejszenie siły oddziaływania bodźca na system powoduje zmniejszenie siły reakcji systemu na ten bodziec. I odwrotnie, w przypadku sprzężenia zwrotnego dodatniego, wraz ze wzrostem siły oddziaływania bodźca na system rodzinny, wzrasta siła reakcji systemu na niego. Ujemne sprzężenie zwrotne warunkuje utrzymanie stałości w systemie, a dodatnie procesy zmian (Świętochowski, 2014). Ostatecznie przyjmuje się, że optymalne dla systemu rodzinnego jest zachowanie homeostazy w kontekście jego tendencji do stałości i do zmiany jednocześnie. Warto nadmienić, że wraz z rozwojem 
badań nad systemowym rozumieniem rodziny, coraz częściej mówi się nie tyle o homeostazie systemu rodzinnego, ile o jego „dopasowaniu” (fit) ((Drożdżewicz, 1999). Istotne jest więc nie tyle zachowywanie równowagi (pojmowanej statycznie), ile funkcjonalność systemu rodzinnego. O tyle jest on sprawny, o ile jest funkcjonalny w perspektywie indywidualnej, jak i całego systemu rodzinnego.

\section{ZNACZENIE SYSTEMU RODZINNEGO DLA JAKOŚCI ŻYCIA JEGO CZŁONKÓW}

Rodzina, rozumiana jako system powiązanych z sobą osób tworzących spójną całość, stanowi prymarny kontekst rozwoju człowieka (Bakiera, 2006). Zazwyczaj rozpatrywany jest on w odniesieniu do dzieci. Jednak rodzina jest istotnym środowiskiem rozwoju nie tylko dzieci, ale także współtworzących rodzinę dorosłych. Na znaczenie tych zależności zwracają uwagę twórcy modelu bilateralnego oddziaływań w rodzinie. W myśl tej koncepcji istotne znaczenie mają dwukierunkowe relacje rodzice-dziecko, a nie tylko jednostronne przebiegające od rodzica do dziecka. Rozwój indywidualny członków rodziny oraz rozwój systemu jako takiego są współzależne i każda osoba ma istotne znaczenie dla rozwoju systemu. Takie założenie niesie z sobą konsekwencje badawcze i dla systemowej terapii rodzin (Liberska, 2017).

W nauce panuje zgoda co do tego, że to rodzice są fundamentem życia rodzinnego i od nich, ich osobowości, kompetencji, woli, postaw, zależy jakość życia rodzinnego, przynajmniej w pierwszych latach życia, choć i kolejne będą stanowiły konsekwencję tego, jaki ton rodzice nadadzą rodzinie i wewnątrzrodzinnym relacjom od początku ich trwania. V. Satir metaforycznie określa rodziców architektami rodziny (Satir, 2002). Od tego, jak zaprojektują oni budowlę życia rodzinnego, zależeć będzie jego jakość i funkcjonalność. Choć, co oczywiste w myśl teorii systemów rodzinnych, na jakość tej budowli wraz z jej ,użytkowaniem" wpływać będą nie tylko rodzice, ale wszyscy członkowie rodziny.

Wartość rodziny dla życia jej członków, szczególnie rozwijających się w niej dzieci, jest nieprzeceniona. Ze względu właśnie na przemożne znaczenie rodziny w życiu człowieka, nieodzowność tego środowiska dla osobowego rozwoju człowieka, J. Wilk zauważył, że istota człowieczeństwa wiąże się z rodzinnością, używa w tym kontekście na określenie osoby ludzkiej pojęcia homo familiaris (Wilk, 2016).

Rodzina jest szczególnym środowiskiem wychowawczym. Jest ujmowana jako podstawowa grupa społeczna. Ta wyjątkowość, fundamentalne znaczenie rodziny 
wiążą się z określonymi jej cechami. Jest to pierwsze, najwcześniej dostępne człowiekowi i najbliższe mu środowisko wychowawcze o prymarnym znaczeniu. W rodzinie nawiązują się unikatowe, niemożliwe do powtórzenia w żadnej innej grupie społecznej, więzi. Mają one charakter osobisty, cechują się naturalnością, automatycznością, nierozerwalnością. Relacje uczuciowe są bardzo silne, a przynależność naturalna. Doświadczenia wyniesione $\mathrm{z}$ domu rodzinnego stanowią fundament kształtowania się człowieka. Wskazane cechy pozwalają na określenie rodziny jako grupy pierwotnej (Kawula, 2009; Wałęcka-Matyja, 2014).

Rodzina jest środowiskiem, które w najpełniejszy sposób może odpowiedzieć na fundamentalne ludzkie potrzeby, takie jak potrzeba miłości, akceptacji, bezpieczeństwa czy uznania. Co więcej, funkcje związane z realizacją tych potrzeb są niedelegowalne, ich natura nie pozwala na to, aby zostały zaspokojone tak samo jak w rodzinie przez inne osoby czy instytucje. Niedomaganie rodziny w tych zakresach w sposób konieczny pociąga za sobą negatywne konsekwencje dla rozwoju członków rodziny. $Z$ biegiem lat pojawiają się oczywiście nowe potrzeby, które związane są z osobami spoza rodziny pochodzenia (np. relacji koleżeńskich), jednak i ich pojawienie się oraz realizacja są związane z jakością wcześniejszych relacji wewnątrzrodzinnych. Jak wynika z badań K. Skrzypińskiej, bliskie relacje rodzinne bezpośrednio wiążą się z poczuciem dobrostanu członków rodziny, i rodziców, i dzieci. $\mathrm{W}$ rodzinie mogą być spełnione podstawowe potrzeby ludzkie - miłości i przynależności, będące fundamentem ogólnego zadowolenia z życia. Jak wskazuje psycholog, wszystko zaczyna się od poszczególnych członków rodziny (Skrzypińska, 2010).

Rodzina jako system, a więc i poszczególni jej członkowie, w toku swojego życia rozwijają się, doświadczają kryzysów, stają przed koniecznością realizacji coraz to nowych zadań. Jak wskazuje E. Street, zmiana jest naturalną konsekwencją rozwoju. W systemie rodzinnym można mówić o zmianach pierwszego i drugiego rzędu. Zmiany pierwszego rzędu to te, kiedy osoba w rodzinie zaczyna robić coś innego lub robić coś inaczej, zachowywać się w inny niż dotychczas sposób. Zgodnie z systemowym rozumieniem rodziny, zmiany w jednym elemencie systemu pociągają nieuchronnie za sobą zmiany w funkcjonowaniu wszystkich jego elementów. $Z$ tą zasadą związane są zmiany drugorzędowe. Są one naturalną konsekwencją zmian pierwszorzędowych. W wyniku zmian pierwszego rzędu (np. osiągnięcia umiejętności chodzenia przez dziecko), pojawiają się zmiany drugiego rzędu - będące reakcją na dostrzeżoną zmianę pierwszego rzędu, wśród pozostałych członków rodziny (rodzice dokonują między sobą nowego podziału obowiązków w związku z koniecznością zwrócenia większej uwagi na 
chodzące już dziecko) (Street, 2013). Od umiejętności członków rodziny, w szczególności rodziców, elastycznego odpowiadania na naturalnie pojawiające się w życiu rodzinnym zmiany i adaptowania się do nowych sytuacji zależą warunki rozwoju całej rodziny jako systemu i poszczególnych jego członków (choć nie jest to jedyna zmienna).

W powyższym kontekście należy powiedzieć, że dynamika życia rodzinnego warunkowana jest naturalnymi procesami rozwojowymi, które określa się mianem cyklu życia rodziny. Rodzina jako system zmienia się w czasie, dążąc równocześnie do zachowania równowagi. Istnieje wiele propozycji periodyzacji cyklu życia rodzinnego. Niemniej, można wyróżnić pewne typowe okresy, przez które przechodzi większość rodzin, choć każda na swój unikalny sposób. Od tego czy i w jaki sposób rodzina poradzi sobie z naturalnymi kryzysami poszczególnych okresów i typowymi dla nich zadaniami zależy jakość kolejnego etapu życia rodzinnego, a więc i jakość życia każdego członka rodziny (Ostoja-Zawadzka, 1999).

W cyklu swojego życia rodzina musi mierzyć się z kryzysami normatywnymi (np. urodzenie dziecka, opuszczenie przez nie domu rodzinnego), a także niekiedy z kryzysami nienormatywnymi, inaczej nieprzewidywalnymi (np. przedwczesną śmiercią bliskiej osoby, nagłą utratą zdrowia). W procesie radzenia sobie z tymi kryzysami, znaczą rolę odrywają właściwości danej rodziny, a więc to czy i jak zachowuje ona stabilność swojej struktury oraz jakie ma umiejętności adaptacji do zmieniającej się sytuacji. Rozwój i zmiany zachodzące w rodzinie jako całości stanowią jeden proces, ale towarzyszy mu równoległy proces dorastania i rozwijania autonomii oraz indywidualnej tożsamości poszczególnych członków rodziny. Zakłócenia w funkcjonowaniu rodziny mogą wynikać albo z niezaspokojonych potrzeb poszczególnych członków rodziny, albo z zakłóceń w realizacji celów rodzinnych, albo obu tych przyczyn jednocześnie (Sokołowska, 2015). To pokazuje, jak znaczne są zależności jakości funkcjonowania rodziny jako całości i poszczególnych jej członków.

\section{ISTOTA SYSTEMOWEJ TERAPII RODZIN}

Początku rozwoju systemowej terapii rodzin upatruje się w latach pięćdziesiątych XX wieku, kiedy to zaczęto dostrzegać istotną rolę rodziny w funkcjonowaniu pacjentów. Początkowo wątki te były rozwijanie w nurcie terapii psychodynamicznej. Krok milowy w rozwoju systemowego kierunku myślenia dokonał G. Beatson badający wpływ rodzin na przebieg schizofrenii pacjentów. Pierwsze 
koncepcje systemowej terapii rodzin, których propagatorami byli m.in. S. Minuchin, P. Watzlawik, J. Halay, opierały się na analogii funkcjonowania rodziny do systemu cybernetycznego, gdzie szczególnie ważne znaczenie miały wbudowane procesy zmierzające do takiej adaptacji systemu rodzinnego, aby mógł on zachowywać homeostazę. $\mathrm{Z}$ biegiem czasu akcent $\mathrm{z}$ mechanicznego rozumienia systemu rodzinnego został przełożony na analizę wpływu, jaki wywierają wartości, przekonania i narracje członków rodziny na ich wzajemną komunikację i łączące ich relacje. Ten nurt myślenia, związany ze szkołą mediolańską i osobą L. Hoffmana, przyczyn problemów klientów poszukuje w odmiennych sposobach oceniania i wartościowania różnorodnych zdarzeń przez poszczególnych członków rodziny. Sposobem na poprawę sytuacji jest zmiana perspektywy i kontekstu sytuacji problemowej, dzięki której możliwe staje się osiągnięcie zamierzonego celu terapeutycznego. W ostatnich latach w praktyce terapeutycznej są wykorzystywane najnowsze koncepcje teoretyczne dotyczące systemowej terapii rodzin, jak i w nowatorski sposób te pierwotne związane z cybernetyką I i II rzędu (Street, 2013; Namysłowska, 1997).

Z przyjęcia systemowej perspektywy życia rodzinnego wynikają określone konsekwencje teoretyczne i praktyczne dotyczące terapii. Terapia rodzinna nie tyle jest tradycyjną formą psychoterapii, prowadzoną nie indywidualnie, a w powiększonym gronie, ile „opiera się na założeniu, że istota trudności w funkcjonowaniu poszczególnych członków rodziny najczęściej nie tkwi w nich samych, lecz w ich wzajemnych relacjach" (Kubitsky, 2010, s. 18). W kontekście terapeutycznym, szczególnie ważna jest zatem analiza systemu rodzinnego pod kątem jego funkcjonalności. Funkcjonalność rodziny objawia się w sposobach radzenia sobie $\mathrm{w}$ poszczególnych etapach cyklu życia rodzinnego, przebiegu procesów rozwojowych rodziny czy też radzeniu sobie z nieprzewidzianymi wydarzeniami losowymi i stresem (Bajkowski, 2018).

Terapia rodziny bywa niekiedy utożsamiana z terapią systemową. Tu konieczne jest jednak doprecyzowanie. Nie każda terapia rodzinna jest terapią systemową. Podobnie, nie każda terapia w nurcie systemowym, musi być terapią rodzinną. Systemowa terapia rodzin opiera się na ogólnej teorii systemów i wypracowanym na jej gruncie systemowym rozumieniu rodziny. Odnosi się ona w głównej mierze do wewnątrzrodzinnych relacji i wynikających z nich konsekwencji, postrzegając je przez pryzmat konstruktywizmu społecznego (Pietras, 2014, s. 528-530). To odróżnia ją od innych kierunków terapeutycznych.

W systemowej terapii rodzin przyjmuje się założenie, że rodzina jest systemem, który posiada zdolność do samoregulacji. Każda rodzina posiada własne 
wzorce i mechanizmy komunikowania się. Każde zaś zachowanie członków rodziny ma charakter komunikatu. Niekiedy te komunikaty są lub stają się (z biegiem czasu, w obliczu nowych okoliczności) przyczyną trudności w życiu rodzinnym i obniżają poziom satysfakcji z wzajemnych relacji. Aby zmienić ten stan rzeczy, konieczna jest zmiana rzeczonych wzorców i mechanizmów komunikowania się (Namysłowska, 1997).

Zdaniem V. Satir, kluczowym pojęciem w terapii jest dojrzałość. Amerykańska terapeutka, jedna $\mathrm{z}$ prekursorek terapii rodzin, wiąże ją z kompetencjami komunikacyjnymi umożliwiającymi osobom realizację funkcjonalnych wzorców zachowań. O dysfunkcjach $\mathrm{w}$ tym zakresie mówi się wtedy, gdy człowiek nie potrafi właściwie postrzegać i interpretować samego siebie, innych osób i przekazów z zewnątrz. W takim przypadku założenia, na których człowiek niedojrzały opiera swoje działania, są błędne, a wysiłki związane z przystosowaniem do rzeczywistości skazane na niepowodzenie (Satir, 2000). Konsekwencje nieumiejętności komunikowania się z samym sobą, z innymi osobami i otaczającą rzeczywistością mogą być brzemienne w skutkach. Zdolności komunikacyjne umożliwiają rozwój człowieka, są czymś swoiście ludzkim. Uwypukla to termin homo communicans, wskazujący na to, że to zdolności komunikacyjne człowieka czynią go koroną stworzenia. Przyczyny niedojrzałości człowieka w kwestii komunikacji mogą mieć niezwykle złożoną naturę i bardzo często ich przyczyna leży w rodzinie pochodzenia klientów. Systemowa terapia rodzin zwraca szczególną uwagę na osobową komunikację, upatrując $\mathrm{w}$ niej jedno $\mathrm{z}$ ważnych źródeł wewnątrzrodzinnych trudności.

Dzięki naukowcom $\mathrm{z}$ zespołu mediolańskiego dostrzeżono znaczenie gier rodzinnych $\mathrm{w}$ systemowej terapii rodzin. Ich zdaniem, członkowie rodziny nieustannie, zwykle w nieuświadomiony dla siebie sposób, prowadzą swoistą grę z pozostałymi członkami rodziny. Gra ta polega na dążeniu do uzyskania potwierdzenia wysyłanych przez siebie komunikatów u pozostałych członków rodziny oraz próbach kontrolowania definicji łączących ich relacji. W prowadzonych grach jej członkowie dążą do tego, aby ich gra nie została zdemaskowana przez pozostałych członków rodziny. Zdaniem twórców mediolańskiej szkoły, gry są dziedziczone $\mathrm{w}$ rodzinach, intensyfikują się wraz $\mathrm{z}$ kolejnymi pokoleniami posługującymi się nimi, a ich trwanie podtrzymywane jest przez wewnętrzy imperatyw rodzinnej lojalności (Namysłowska, 1997). W tym kontekście można powiedzieć, że istotą systemowej terapii rodzinnej jest dostrzeżenie realizowanych wzorców i mechanizmów komunikacji oraz prowadzonych wśród członków 
rodziny gier i wypracowanie nowych, bardziej użytecznych sposobów podtrzymywania i rozwijania relacji wewnątrzrodzinnych.

Systemowa terapia rodzinna, oparta na założeniach konstruktywizmu społecznego, koncentruje się na znaczeniach nadawanych przez członków rodziny ważnym dla nich kwestiom. Przyjmuje się, że różnice w tych znaczeniach są jedną $\mathrm{z}$ przyczyn trudności $\mathrm{w}$ funkcjonowaniu systemu rodzinnego. Istotnym celem $\mathrm{w}$ tym kontekście jest prowadzenie takiego dialogu, który umożliwi członkom rodziny wyjście poza dotychczas nadawane przez siebie znaczenia, dostrzeżenie różnic $\mathrm{w}$ znaczeniach nadawanych przez poszczególnych członków rodziny i wypracowanie nowego systemu znaczeniowego rodziny. To pozwala przejść z pozycji koncentracji na problemie do dialogu, który nie jest już na nim zogniskowany (Namysłowska, 1997).

W trakcie terapii systemowej rodziny uwaga najczęściej skupia się na łączących członków rodziny relacjach i ich wzajemnych interakcjach. Wspólne poszukiwanie drogi prowadzącej do zwiększenia satysfakcji w problemowym obszarze odbywa się między innymi za sprawą interwencji terapeuty. Polegają one na wprowadzaniu takich informacji, aby członkowie rodziny mogli uzyskać nową perspektywę oglądu danego problemu. Dzięki temu możliwe staje się wprowadzenie zmian drugiego rzędu (Street, 2013). W systemowej terapii rodzin ważne jest, aby klienci uzyskali nowe informacje o nurtującym ich problemie. Ma to służyć przede wszystkim temu, aby klienci dostrzegli i zrozumieli swoisty sposób interakcji $\mathrm{w}$ ich rodzinie i mechanizmy budowania więzi pomiędzy poszczególnymi członkami rodziny. Dzięki temu zyskują oni szansę dostrzeżenia problemu z innej perspektywy, a tym samym nowych sposobów rozwiązania go (Street, 2013). Ten etap oczywiście nie wyczerpuje systemowej terapii rodzin, ale jest koniecznym elementem na drodze ku sprawniejszemu funkcjonowaniu rodzinnemu.

Systemowa terapia rodzin w znacznie większej mierze niż większość kierunków psychoterapii indywidualnej zorientowana jest na cel (Kubitsky, 2010). Może być on różnorodnie definiowany, w zależności od doświadczanych trudności w życiu rodzinnym, jednak zazwyczaj mieści się on $\mathrm{w}$ kategorii poprawy jakości życia rodzinnego lub rozwiązania konkretnego problemu. Ze względu na wielość problemów, których może doświadczać rodzina, przyjmuje się, że kontekst systemowej terapii rodzin jest multidyscyplinarny (Street, 2013). To implikuje wysokie wymagania merytoryczne stawiane systemowym terapeutom rodzinnym. Ich wiedza, aby była adekwatna do materii systemowej terapii rodzin, powinna mieć charakter interdyscyplinarny i być nieustannie pogłębiana. 
Przedmiotem bowiem systemowej terapii rodzin mogą być różnorodne problemy indywidualne oraz relacyjne.

Systemowa terapia rodzin jest terapią interakcyjną. Ważna jest w niej relacja, jaka łączy klientów i terapeutę. Zdaniem L.M. Brammera, osoba pomagającego jest równie ważna, jak metody, których używa (Brammer, 1984). Dzięki określonym cechom osobowościowym oraz umiejętnościom nawiązywania i podtrzymywania kontaktu, możliwe staje się zbudowanie relacji, która sama w sobie ma walor terapeutyczny. Choć nie ma określonego wzorca cech służących efektywnemu pomaganiu, to jednak $\mathrm{w}$ toku badań dostrzeżono pewne przymioty terapeutów, które sprzyjają podejmowaniu zmian i rozwojowi klientów. Należą do nich między innymi świadomość siebie i własnego systemu wartości, ciekawość innych ludzi, ich świata doświadczeń i przeżyć, empatia, ciepło i opiekuńczość, otwartość czy wreszcie pozytywny, wykluczający ocenę, afirmatywny stosunek do klientów (Brammer, 1984, s. 29-47). Systemowy terapeuta rodzinny spełnia także rolę modela w kwestii komunikacji. Jeśli, jak zostało powyżej przedstawione, jednym $\mathrm{z}$ głównych wątków terapeutycznych jest umiejętność komunikacji, to terapeuta może stać się dla klientów osobą znaczącą w kwestii dostarczania właściwych wzorców komunikacyjnych (Satir, 2000).

Te cechy terapeutów ważne są między innymi z tego względu, że pomagają osiągnąc szczerą, opartą na zaufaniu relację terapeutyczną. W niej terapeuta i klienci mogą zrozumieć funkcjonowanie systemu rodzinnego, zyskać nową perspektywę jego oglądu oraz wspólnie wypracować, wprowadzić i zweryfikować określone zmiany. Systemowi terapeuci rodzinni dysponują szeregiem metod i technik użytecznych w realizacji celów terapeutycznych. Należą do nich między innymi odzwierciedlanie, pytania skalujące, pytania o cud, pytania cyrkularne, praca $\mathrm{z}$ genogramem, rozmowa eksternalizująca, makro- i mikrointerwencje, pytania o różnice, bajki terapeutyczne, tworzenie alternatywnych narracji, technika wyjątków, uzgadnianie celów, rytuały rodzinne czy pytania hipotetyczne. O dobrze metody i techniki decyduje jej użyteczność dla klienta. Systemową terapię rodzinną wyróżnia podmiotowe odniesienie do klientów, w którym uznanie ich indywidualności i niepowtarzalności stanowi ważną wytyczną dla pracy terapeutów. Każdy system rodzinny jest niepowtarzalny i wymaga otwartości w pracy $\mathrm{z}$ nim. Nie ma w tym miejscu konieczności szczegółowego prezentowania poszczególnych metod i technik terapeutycznych. Ważne jest to, aby służyły one klientom i terapeutom w dostrzeżeniu dynamiki systemu rodzinnego, a przez to wypracowaniu bardziej satysfakcjonujących rozwiązań, dzięki którym zgłaszane problemy staną się mniejsze lub przestaną istnieć. 
Trudno jest dowodzić o uśrednionym czasie trwania systemowej terapii rodzin. Jest to indywidualna kwestia, jednak istnieje pewne dążenie, aby nie trwała ona dłużej, niż przemawia za tym konieczność. Widać tu pewne podobieństwo systemowej terapii rodzin do krótkich terapii zorientowanych na rozwiązanie problemu. Satysfakcja ze skuteczności systemowej terapii rodzin wynosi ok. $80 \%$ i jest maksymalna w czasie około szóstego-ósmego spotkania. Jak twierdzi K. Ludewig, „od tego momentu trzeba przeprowadzić nieproporcjonalnie więcej seansów, aby znowu osiągnąć postęp" (Ludewig, 1995). W systemowej terapii rodziny może uczestniczyć każdy członek systemu rodzinnego, również dzieci, niezależnie od ich wieku.

\section{UŻYTECZNOŚĆ SYSTEMOWEJ TERAPII RODZINY}

Możliwości zastosowania systemowej terapii rodziny są szerokie. W szczególności jest ona zasadna $w$ przypadkach normatywnych i nienormatywnych kryzysów w rodzinie, kryzysów związanych z mechanizmami działania systemu rodzinnego, np. procesami morfostatycznym i morfogenetycznym, trudności poszczególnych członków rodziny - niezależnie od ich etiologii, konfliktów w rodzinie, przemocy w niej, zaburzeniach odżywiania czy schizofrenii jednego z członków rodziny. Zasadna jest również w przypadku kryzysów rozwojowych $\mathrm{w}$ rodzinie, jednak tu konieczna jest rozwaga i zastosowanie zasady pomocniczości. Kryzysy rozwojowe pojawiają się w cyklu życia rodziny w sposób naturalny, są jego nieodłącznym i koniecznym elementem. Sam fakt pojawienia się kryzysu rozwojowego w rodzinie (np. związanego z przyjściem na świat potomka czy też okresem buntu dorastającego dziecka) nie jest jeszcze wskazaniem do podjęcia systemowej terapii rodziny. Jeśli jednak członkowie rodziny lub chociażby jeden $\mathrm{z}$ nich, mają poczucie, że doświadczany kryzys przebiega nietypowo, trwa zbyt długo, powoduje zbyt silne obciążenie systemu rodzinnego, warto skonsultować się ze specjalistą. O ile kryzysy normatywne nie wymagają w większości przypadków interwencji terapeutycznej, o tyle jest ona zasadna w przypadku nienormatywnych kryzysów rodzinnych, takich jak na przykład nagła utrata pracy czy poważna choroba jednego z członków rodziny. Udział w systemowej terapii rodzinnej może przyczynić się do zachowania homeostazy systemu rodzinnego z jednej strony i elastyczności w dostosowaniu się do nowej sytuacji z drugiej. 
Istnieją sytuacje, w których udział wyłącznie w systemowej terapii rodzin jest niewystarczający i konieczne jest podjęcie innego rodzaju leczenia. Należą do tych sytuacji głęboka, psychotyczna depresja, ostra psychoza, uzależnienie czy choroby afektywne (de Barbaro, Namysłowska, 2012). Należy stwierdzić, że efektywność systemowej terapii rodzin uzależniona jest w tego typu przypadkach od tego, czyli klienci podejmują równolegle inne formy terapii. Dotyczy to w szczególności rodzin, w których ich członkowie cierpią na zaburzenia lękowe, zachowania lub odżywiania, poważne choroby psychiczne, uwikłani się w nałogi, a także rodzin, których członkowie doświadczają przemocy domowej lub seksualnej. W tych i podobnych im przypadkach, skuteczność systemowej terapii rodzin wzrasta wtedy, kiedy klienci realizują jednocześnie inne, specjalistyczne terapie (Street, 2013). Niemniej, w tych wszystkich sytuacjach, systemowa terapia rodzinna może okazać się bardzo pomocna. Każdy bowiem z tych przypadków generuje określone trudności w funkcjonowaniu systemu jako takiego. Nierzadko system rodzinny podtrzymuje syndromy chorobowe jednego z członków rodziny. Można $\mathrm{z}$ odwagą stwierdzić, że systemowa terapia rodzinna może mieć swoje wartościowe zastosowanie w przypadku wszystkich osób żyjących w rodzinach, choć niekiedy, jak wskazano powyżej, nie powinna być jedyną formą pomocy.

Istnieje niewiele badań empirycznych dotyczących skuteczności systemowej terapii rodzinnej, szczególnie tych prowadzonych w strategii ilościowej. $\mathrm{Z}$ badań, które dotychczas przeprowadzono wynika, że skuteczność terapii dotyczącej problemów w związku znacznie wzrasta, gdy uczestniczą w niej oboje partnerzy, a nie tylko jeden z nich. Ponadto, większą skutecznością odznaczają się te terapie, które mają charakter krótkoterminowy. K. Ludewig w latach osiemdziesiątych XX w. wskazywał, że najwyższą skuteczność osiąga się około 8. spotkania, E. Street zaś podaje, że krótkoterminowe skuteczne terapie trwać powinny do około 20 spotkań; pomimo tych różnic, panuje zgoda co do tego, że większą skuteczność osiąga się w systemowej terapii rodzin raczej krótko- niż długoterminowej (Street, 2013).

Na trudność w ewaluacji w psychoterapii w ogóle, w tym terapii systemowej rodzin, zwraca uwagę K. Ludewig (Ludewig, 1995). Materia badań uzasadnia ich prowadzenie nie tylko w strategii ilościowej, ale także, a być może przede wszystkim, jakościowej. Zdaniem T. Pietrasa, ,jeśli przyjąć, że badania jakościowe i fenomenologiczne są dobrą metodą oceny tej formy terapii, to można powiedzieć, że systemowa terapia rodzin bez wątpienia pomaga pacjentom i ich rodzinom" (Pietras, 2014, s. 536). 


\section{ZAKOŃCZENIE}

Z badań statystycznych wynika, że zdecydowana większość Polaków wybiera życie w rodzinie jako formę realizacji życiowego powołania oraz że wiele $\mathrm{z}$ tych rodzin ulega $\mathrm{z}$ biegiem lat rozpadowi (https://stat.gov.pl/files/gfx/portalinforma cyjny/pl/defaultaktualnosci/5515/3/11/1/rocznik_demograficzny_2017.pdf; dostęp: 8.07.2019). Rodzina stanowi najważniejsze i niezastępowalne środowisko rozwoju człowieka, od kondycji którego zależy jakość jego dalszego życia. Ponadto, ponowoczesność przynosi wiele wyzwań dla rodzin. Wszystko to sprawia, że zasadnym jest poszukiwanie coraz to nowych form wsparcia rodziny, aby jej funkcjonowanie było korzystne dla tworzących rodzinę osób.

Systemowa terapia rodziny może stanowić skuteczne źródło pomocy dla poszczególnych członków rodziny i całej rodziny jako systemu. Jak wynika z systemowego rozumienia rodziny, tych dwóch rzeczywistości nie sposób od siebie oddzielić. Często problemy pojedynczych osób wynikają z niewłaściwego funkcjonowania rodziny jako całości, często także to one są źródłem powstawania trudności w realizacji zadań systemu rodzinnego.

Podsumowując, w tego rodzaju terapii może wziąć udział każdy człowiek, niezależnie od swojego stanu rodzinnego i życiowego. Przedmiotem systemowej terapii są zazwyczaj trudności wynikające $\mathrm{z}$ panujących $\mathrm{w}$ systemie rodzinnym (aktualnym lub w rodzinie pochodzenia) relacji, relacji w podsystemach i pomiędzy nimi, trudności wynikające z zachowania lub rekonstruowania granic systemu rodzinnego, odpowiadania na pojawiające się w życiu rodzinnym zmiany, trudności związane z normatywnymi kryzysami w cyklu życia rodzinnego oraz kryzysami nienormatywnymi. Jest to odpowiednia forma terapii dla każdej osoby, która doświadcza niesatysfakcjonujących relacji wewnątrzrodzinnych, których przyczyny mogą być niezwykle zróżnicowane, a także innych problemów, nawet z pozoru niezwiązanych z życiem rodzinnym. Systemowa terapia rodzin posiada wypracowane metody i techniki pozwalające na przybliżenie się do źródła doświadczanych trudności i przezwyciężenie ich.

\section{BIBLIOGRAFIA}

BAJKOWSKI, T. (2018). U źródeł tożsamości rodzinnej. System rodzinny w percepcji młodzieży akademickiej. Warszawa: Wydawnictwo Naukowe Scholar.

BAKIERA, L. (2006). Rodzina z perspektywy socjologicznej i psychologicznej. Ciągłość i zmiana. Roczniki Socjologii Rodziny, 17(2006), 101-115.

BAUMAN, Z. (2011). 44 listy ze świata płynnej nowoczesności. Kraków: Wydawnictwo Literackie. 
Brammer, L.M. (1984). Kontakty stużące pomaganiu. Procesy i umiejętności. Warszawa: Polskie Towarzystwo Psychologiczne.

DE BARbaro, B. (1997). Pacjent w swojej rodzinie. Warszawa: Springer PWN.

DE BARbaro, B., NAmysŁowsKa, I. (2012). Terapia rodzinna. W: S. PużyŃSKi, J. RYBAKowski, J. WCióRKA (red.), Psychiatra. T. 3 (s. 311-329). Wrocław: Elsevier Urban \& Partner.

DEISSLER, K. (1998). Terapia systemowa jako dialog. Kraków: Wydawnictwo Uniwersytetu Jagiellońskiego.

DrożDżEWICZ, L. (1999). Ogólna teoria systemów. W: B. de BARBARo (red.), Wprowadzenie do systemowego rozumienia rodziny (s. 9-17). Kraków: Wydawnictwo Uniwersytetu Jagiellońskiego.

JÓzEFIK, B. (2003). Rozwój myślenia systemowego a terapia rodzin. W: L. GÓRNIAK, B. JÓzEFIK (red.), Ewolucja myślenia systemowego w terapii rodzin. Od metafory cybernetycznej do dialogu i narracji (s. 19-31). Kraków: Wydawnictwo Uniwersytetu Jagiellońskiego.

KAWULA, S. (2009). Rodzina jako grupa i instytucja opiekuńczo-wychowawcza. W: S. KAwULA, J. Brą̧Giel, A.W. Janke (red.), Pedagogika rodziny. Obszary i panorama problematyki (s. 4781). Torun: Wydawnictwo Adam Marszałek.

KUBITSKY, J. (2010). Vademecum terapeuty rodzinnego. Warszawa: Wydawnictwo Lekarskie PZWL.

KwAK, A. (2005). Rodzina w dobie przemian. Matżeństwo i kohabitacja. Warszawa: Wydawnictwo Akademickie ,Żak”.

LibersKa, H. (2017). Rozwój rodziny i rozwój w rodzinie. W: I. JANICKA, H. LibersKa (red.) Psychologia rodziny (s. 221-240). Warszawa: Wydawnictwo Naukowe PWN.

LudewIG, K. (1995). Terapia systemowa. Podstawy teoretyczne i praktyka. Gdańsk: Gdańskie Wydawnictwo Psychologiczne.

NAMYSŁOWSKA, I. (1997). Terapia rodzin. Warszawa: Springer PWN.

Ostoja-ZawadzKa, K. (1999). Cykl życia rodzinnego. W: B. DE BArbaro (red.). Wprowadzenie do systemowego rozumienia rodziny. Kraków: Wydawnictwo Uniwersytetu Jagiellońskiego.

Piertas, T. (2014). Współczesne nurty w terapii rodzin. W: I. JANicKA, H. LibersKa (red.). Psychologia rodziny (s. 528-536). Warszawa: Wydawnictwo Naukowe PWN.

SATIR, V. (2002). Rodzina. Tu powstaje człowiek. Gdańsk: Gdańskie Wydawnictwo Psychologiczne.

SATIR, V. (2000). Terapia rodziny. Teoria i praktyka. Gdańsk: Gdańskie Wydawnictwo Psychologiczne.

SKRZYPIŃSKA, K. (2010). Relacje rodzinne a dobrostan psychiczny w perspektywie rozwojowej. W: T. RostowsKa, A. JARMOŁOWSKA (red.), Rozwojowe i wychowawcze aspekty życia rodzinnego. Warszawa: Difin.

SoKOŁOWSKA, E. (2015). Psychospołeczne uwarunkowania trudności związanych z realizacją zadań rozwojowych. W: J.C. CzaBAŁA (red.), Poradnictwo psychologiczne. Warszawa: Wydawnictwo Naukowe PWN.

Street, E. (2013). Terapia rodzinna i systemowa. W: C. Feltham, I. Horton (red.), Psychoterapia i poradnictwo. T. 2 (s. 333-340). Gdańsk: Gdańskie Wydawnictwo Psychologiczne.

ŚwięTOCHOwSKI, W. (2017). Rodzina w ujęciu systemowym. W: I. JANICKA, H. LiberSKA (red.) Psychologia rodziny (s. 21-45). Warszawa: Wydawnictwo Naukowe PWN.

WatęCKA-MAtyja, K. (2015). Role i funkcje rodziny. W: I. JANicka, H. Liberska (red.). Psychologia rodziny (s. 95-114). Warszawa: Wydawnictwo Naukowe PWN.

WILK, J. (2016). Pedagogika rodziny. Lublin: Wydawnictwo Episteme. 


\section{TERAPIA SYSTEMOWA JAKO FORMA POMOCY RODZINIE}

\section{Streszczenie}

Artykuł przedstawia terapię systemową jako możliwą i skuteczną formę pomocy rodzinie. Przedstawione są w nim treści dotyczące systemowego rozumienia rodziny oraz znaczenia rodziny dla jakości życia jej członków. Główną część tekstu stanowią refleksje na temat istoty systemowej terapii rodzin oraz jej użyteczności.

Slowa kluczowe: systemowa terapia rodzin; system rodzinny; terapia; pomoc rodzinie.

\section{SYSTEMATIC THERAPY AS A FAMILY HELPING FORM}

\section{S u m m a r y}

The article shows systematic therapy as a possible and effective family helping form. There are described: family as a system and the importance of the family system to life quality of its members. The main part of the article is about the essence of systematic family therapy and utility of this form of therapy.

Key words: systematic family therapy; family system; therapy; family helping form. 